\title{
WHAT DRIVES COMMUNITY FLOOD RISK MANAGEMENT? POLICY DIFFUSION OR FREE-RIDING
}

\author{
DOUGLAS S. NOONAN ${ }^{1}$, LILLIARD E. RICHARDSON ${ }^{2}$, ABDUL-AKEEM SADIQ $^{3}$ \& JENNA TYLER ${ }^{3}$ \\ ${ }^{1}$ Indiana University-Purdue University Indianapolis. \\ 2 Pennsylvania State University. \\ ${ }^{3}$ University of Central Florida, United States.
}

\begin{abstract}
This study explores whether participation in the US Federal Emergency Management Agency's Community Rating System (CRS), a voluntary community flood risk management program, is a function of policy diffusion or an act of free-riding. Policy diffusion would suggest that, all else being equal, once a community has joined the CRS, neighboring communities will be more likely to follow their lead and participate in the CRS. Free-riding would imply that neighboring communities might choose not to participate in the CRS because they perceive that their community benefits from surrounding communities' participation. Results indicate that a community's decision to participate in the CRS is not influenced by the characteristics of or the behavior of their neighbors. The results of this study do, however, show that population density, aggregate housing values, rentership rate, and flat topography are significant predictors of CRS participation.
\end{abstract}

Keywords: Community Rating System, community flood risk management, free-riding policy diffusion.

\section{INTRODUCTION}

Flooding remains the most destructive natural hazard in the United States (US) and around the world. In fact, a 2013 report indicates that 53 percent of those that died from natural disasters in 2012 died as a result of flooding [1]. Data from the US National Weather Service (NWS) show that, on average, 116 individuals died annually as a result of flooding between 2008 and 2017 [2]. In light of recent flood disasters and predictions of increased flood risks fueled by global climate change, there is a need for greater flood risk management at the community level.

The US Federal Emergency Management Agency (FEMA) established the Community Rating System (CRS) program to reduce future flood losses and improve community flood resilience. The CRS is a federal, voluntary community flood risk management program. Communities that participate in the CRS are required to adopt additional floodplain management activities and, in return, community members receive reductions in their flood insurance premiums. Studies examining the CRS have shown that a number of factors influence CRS participation such as local flood risks, fiscal capacity, and socioeconomic characteristics [3], [4]. This study builds on this work and explores whether CRS participation is a function of policy diffusion or an act of free-riding. Policy diffusion would suggest that, all else being equal, once a community has joined the CRS, neighboring communities will be more likely to follow their lead and participate in the CRS. Stated differently, neighboring communities might realize the benefits of participation in the CRS in terms of reduced flood losses and discounts in flood insurance premiums and decide to participate in the CRS program. Conversely, neighboring communities might choose not to participate in the CRS because they perceive that their community benefits from surrounding communities participating in the CRS, thus, exhibiting free-riding behavior. In other words, the neighbor's risk mitigation efforts could reduce potential damage from floods for the nearby communities who do not participate in the CRS. The authors test these competing hypotheses using secondary data 
from US government organizations such as FEMA, US Department of Transportation (USDOT), and US Census Bureau.

The remainder of this paper is organized as follows. The next section reviews relevant literature and provides a background on the CRS program. The third section discusses the research design while the fourth and fifth sections present the data and results, respectively. This paper concludes with a discussion of study findings.

\section{LITERATURE REVIEW}

\subsection{Background on the community rating system program}

The US Congress passed the National Flood Insurance Program (NFIP) in 1968. This program provides federally backed flood insurance for properties in floodplains where the local community has passed and enforced certain measures that regulate development in floodplains and mitigate the damage once a flood has occurred. Homeowners in NFIP participating communities can purchase flood insurance and, in exchange, their state and local governments enact and enforce floodplain management ordinances [5]. Over 22,000 communities participated in the NFIP as of October 2016, and over five million residential and commercial properties in those eligible communities had flood insurance coverage. From 1978 to 2016, over 2.2 million flood insurance claims were filed, and the claimed losses exceeded $\$ 54$ billion. In 2016 , over $\$ 1.25$ trillion in property value were covered by flood insurance, and those property owners were paying premiums of about $\$ 3.6$ billion for that coverage [6].

The NFIP is a flood mitigation management initiative that shares risks and burdens among the federal government, state and local governments, and private insurance companies [7]. The NFIP is fraught with problems such as low insurance premium rates and increased development in floodplains [7]. As a result of these and other programmatic issues, flood losses are substantial and increasing annually [6], [7]. Consequently, Congress gave FEMA the mandate to establish the CRS with the National Flood Insurance Reform Act of 1994 with a view to providing additional incentives to communities already participating in the NFIP to reduce their flood risks [6].

FEMA developed the CRS program, a voluntary program that provides a point system for a set of community actions and policies that reduce flooding hazards and mitigate damages from flooding, to encourage communities to exceed the minimal regulatory standards set by the NFIP. As a reward, property owners in covered floodplains within communities may receive discounted flood insurance premiums with larger premium discounts available for those communities who rate better on the CRS.

FEMA established a set of CRS levels that range from ten (the worst rating) to one (the best rating). The discounts in flood insurance premiums start at level nine with a five percent greater reduction for each level on the scale until a community reaches a class one and receives a $45 \%$ discount. Communities interested in joining the CRS must participate in the NFIP and can apply each year to FEMA for evaluation. Furthermore, participating CRS communities are required to recertify annually. Communities can improve their CRS rankings if they have implemented additional creditable activities, thus causing residential and commercial property owners to experience an additional reduction in their flood insurance premiums. If a community is not in compliance or fully implementing the credited activities, however, their CRS classification might be revised [6]. 
Several of the CRS components relate to information needed for improved hazard planning, and the foundational information for much of this works is the Flood Insurance Rate Map (FIRM). Similarly, the first component, elevation certificates (code 310), is required for anyone wanting to qualify under the CRS as a level nine community (which is the start of the flood insurance discount levels). The optional Map Information Services component (\#320) is primarily about foundational information needed for enhanced hazard planning. A further component that is primarily about the creation of data for planning purposes is flood data maintenance (\#440), which rewards digital storage for new and old FIRM records, GPS data and digitized maps. Overall, these informational components are necessary for a community or property owners to engage in the other CRS activities, but they do not directly affect the reduction of flooding or mitigation of the damage after a flood.

\subsection{Predictors of CRS participation}

Studies examining the CRS have largely focused on the determinants of community participation [3], [8], the use of the CRS as a measure of adaptive capacity of municipal leaders to engage in collective action [9], and policy learning [10]. Others have investigated the characteristics of communities that are behaving strategically to take advantage of the incentive structure of the CRS [4], and CRS effects on flood insurance demand [5], [11]. More recently, scholars have examined the unintended consequences of the CRS such as the effects of the CRS on migration and development [12] and income inequality [13]. Extant research shows that CRS participation is more prevalent in communities with higher flood risks, population sizes, incomes, owner occupied housing, educational attainment levels, and proportions of senior citizens [3], [8], [9], [14]-[16]. Results also demonstrate that CRS participation is lower in places with higher unemployment, poverty, crime, and minority populations [8], [9], [16]. Furthermore, both [3] and [8] identified local capacity of a government (e.g. payroll, property tax revenue, and capital outlay) to implement programs as important to the decision to participate in the CRS program. Higher adaptive capacity in a community could lead to higher collective action to engage in community flood risk management programs [9], which is consistent with finding that places with stronger institutions suffer less natural disaster damages [17]. Of particular interest to the present study is the findings that CRS participating communities in North Carolina tend to nest together [8]. The current study expands on this work using national level data and by providing a better indication of whether this nesting is a function of policy diffusion or an act of free-riding.

\section{RESEARCH DESIGN}

This study explores whether CRS participation is more of a function of policy diffusion or an act of free-riding. The dependent variable, CRS participation, is a binary variable that is measured as whether or not a community participates in the CRS as of the year 2013.

The base model explores the factors that motivate communities to implement flood hazard mitigation activities and follows with the diffusion aspects in italics:

Mitigation Activity $=\mathrm{f}$ (community flood risk, community characteristics, neighbor mitigation activities, neighbor characteristics $)+\varepsilon$.

The dependent variable, mitigation activity, is any activity a community implements to reduce or eliminate the impacts of flooding. As represented by the equation above, mitigation activity is a function of community's flood risk, community characteristics, neighbor mitigation 
activities, and neighbor characteristics. Community flood risk is determined by factors such as topography, proximity to water, population density in flood plain, weather patterns, etc. Community characteristics include factors such as poverty rates, housing value, resident education levels, real personal income, etc. The neighbor mitigation activities and characteristics are the same set of variables, but moderated through the lens of diffusion and free-rider incentives.

Mitigation Activities is measured using a community's adoption of CRS components. CRS was passed in 1998, and we have the list of communities that joined the CRS on a yearly basis until 2013. Among the over 22,000 communities participating in the NFIP and therefore eligible for CRS, less than 1,300 communities were in the CRS in 2013, and there are approximately 2,100 communities who are neighbors of a community that was in the first cohort of communities to adopt CRS in 1998. We refer to this first cohort of communities to join the CRS from 1998 to 2013 as early leaders, and their neighbor communities as potential followers. We coded CRS implementation as a dummy variable for CRS eligible or not at any point in the time series, and the model could be a hazard model for adoption in a given year. Additional to this cross-sectional model, we estimated a dynamic model that predicts only changes in CRS adoption from 1998-2013, to take advantage of the time series component of the data. Both models look at joining the CRS and not the intensity of participation, and show the drivers and the spatial diffusion process (SMM model's lag), both cross-sectionally (CRS13) and as a change ( $\triangle \mathrm{CRS}$ ). We then use these models to examine which of the neighboring communities' attributes drive joining.

There are several ways to code neighbor mitigation activities and neighbor community characteristics to test for diffusion and free-rider aspects of CRS. The simplest form is as a dummy variable for any neighbor adoption of CRS such as community B or C implementing CRS after leading adopter community A. An alternative would be the percent of community neighbors adopting CRS. Neighbor Mitigation Activity tests for the hazard mitigation implementation activities of community A's neighbors. Neighbor characteristics include flood risk and demographics for those adjacent communities bordering a community. It is measured as an average of all neighboring communities.

So, the variations of the model are as follows:

$$
\mathrm{y}=\rho \mathrm{Wy}+\beta \mathrm{X}+\delta \mathrm{E}+\gamma \mathrm{R}+\theta .
$$

where,

$\mathrm{y}=$ CRS participant in $2013(0,1)$

$\mathrm{y}=$ dummy for whether community joined CRS after $1998(0,1)$

$\mathrm{X}=\mathrm{a}$ vector of demographics from the Census (aggregated up to county/place level from tracts), typically measured in 2000 or 1990, and a few are included as \% changes from 1990 to 2000

$\mathrm{E}=$ vector of 'environmental' or geographic factors such as topography, water cover, humidity, or ruralness

$\mathrm{R}=$ flood risk measured from the USDOT raster map, population-weighted aggregated from the tract level. (Alternates such as area-weighted flood risk and official flood plain designations were also used.)

The $\rho \mathrm{Wy}$ is a 'spatial lag' term, based on a spatial weights matrix W (in our case, an NxN matrix indicating whether observation $i$ and $j$ are 'neighbors' with a 1 and a 0 otherwise). As $\mathrm{W}$ is 'row-standardized' (i.e. each row in the vector adds up to 1), this 'Wy' basically amounts to an average value of y among all of community i's adjacent communities. (If you had 2 out of your 4 neighbors with $\mathrm{CRS}=1$, then $\mathrm{Wy}=0.5$ for you. If it was 1 out of 5 neighbors, then 
$\mathrm{Wy}=0.2$.) The parameter $\rho$ is thus a spatial lag parameter that shows essentially the direct spillover influence of neighbors' y values on one's own y value. A significant and positive $\rho$ is what we are expecting and testing. Wy is endogenous, so the estimator will rely on a set of valid instrumental variables based on the spatial lags of all the other regressors.

The error term $\theta$ can be estimated with a spatial error component: $\theta=\lambda \mathrm{W} \varepsilon+\varepsilon \ldots$ where the $\lambda$ is the spatial autocorrelation parameter and the nuisance or 'error' term is allowed to correlate among neighbors. This will allow us to test for some omitted variables that tend to cluster spatially, which is very likely in this context. We estimate spatial models after the OLS versions of each (estimated with White-corrected standard errors in the presence of heteroskedasticity) by using Spatial Mixed Models (SMM). All the variables and their descriptions are provided in Table 1.

Table 1: Variable descriptions.

\begin{tabular}{|c|c|}
\hline Variable name & Description \\
\hline$\overline{\mathrm{CRS} 13}$ & $\begin{array}{l}\text { Dummy variable: } 1 \text { if community joined the CRS by } 2013,0 \\
\text { otherwise }\end{array}$ \\
\hline$\triangle \mathrm{CRS}$ & $\begin{array}{l}\text { Dummy variable: } 1 \text { if community joined the CRS between } 1998 \\
\text { and 2013, } 0 \text { otherwise }\end{array}$ \\
\hline popdens98 & Community population per area in 1998 \\
\hline srwht00 & $\%$ white in 2000 \\
\hline adult00 & $\%$ adults (age 18 and older) in 2000 \\
\hline kids00 & $\%$ children (under age 5) in 2000 \\
\hline BAshare00 & $\%$ with college degree (or more) in 2000 \\
\hline smenty00 & $\%$ living in same county 5 years prior, in 2000 \\
\hline unemprt00 & $\%$ unemployed in 2000 \\
\hline povrat00 & $\%$ under poverty line in 2000 \\
\hline lnrmdfamInc00 & $\begin{array}{l}\ln \text { (family income) in 2000, inflation adjusted to } 2010 \text { (Popula- } \\
\text { tion-weighted average of tracts' median family incomes) }\end{array}$ \\
\hline lnrmdvalhs 00 & $\begin{array}{l}\text { In(median housing value) in 2000, inflation adjusted to } 2010 \\
\text { (Population-weighted average of tracts' median housing value) }\end{array}$ \\
\hline lnraggval00 & ln(aggregate housing value) in 2000, inflation adjusted to 2010 \\
\hline rentshare 00 & $\%$ of housing units that are renter-occupied in 2000 \\
\hline popgro9000 & Population growth rate from 1990 to 2000 \\
\hline d10BAshare & $\%$ BAshare $10 / \%$ BAshare00 \\
\hline d10rmdfamInc & rmdfamInc10/rmdfamInc00 \\
\hline d10rmdvalhs & rmdvalhs10/rmdvalhs00 \\
\hline d10raggval & raggval10/raggval00 \\
\hline rururb & $\begin{array}{l}\text { Rural-urban influence code ( } 0-9 \text {, with } 9 \text { being more rural), } \\
\text { county-level }\end{array}$ \\
\hline JulHumid & July humidity, county-level \\
\hline watershare & $\%(0-100)$ of county covered in water, county-level \\
\hline flat & Dummy indicating flat topography, county-level \\
\hline
\end{tabular}




\begin{tabular}{|c|c|}
\hline FloodDamMA98 & $\begin{array}{l}\text { Total property damage per capita from major flood events in } \\
\text { county } 1994-1998\end{array}$ \\
\hline FloodDam98 & $\begin{array}{l}\text { Total property damage per capita from major flood events in } \\
\text { county in } 1998\end{array}$ \\
\hline noFIRM & $\begin{array}{l}\text { Dummy indicating community does not have a flood plain map } \\
\text { variable defined }\end{array}$ \\
\hline RiskshareC & $\begin{array}{l}\text { Flood risk (0-99) as an area-weighted average of (average) tract } \\
\text { flood risk in community }\end{array}$ \\
\hline RisksharePWC98 & $\begin{array}{l}\text { Flood risk (0-99) as population-weighted average of (average) } \\
\text { tract flood risk in community in } 1998\end{array}$ \\
\hline d98FloodDamMA & FloodDam598 / FloodDam590 \\
\hline d98RisksharePWC & RiskshareP98 / RiskshareP90 \\
\hline CRS98_W & $\begin{array}{l}\text { Spatial lag (based on contiguity matrix) of dummy variable for } \\
\text { whether community joined CRS by } 1998\end{array}$ \\
\hline CTotal98_W & $\begin{array}{l}\text { Spatial lag (based on contiguity matrix) of community total CRS } \\
\text { points in } 1998\end{array}$ \\
\hline FloodDamMA98_W & Spatial lag (based on contiguity matrix) of FloodDamMA98 \\
\hline Watershare_W & Spatial lag (based on contiguity matrix) of watershare \\
\hline PopGro (predicted)_W & $\begin{array}{l}\text { Spatial lag (based on contiguity matrix) of predicted population } \\
\text { growth rate (linear prediction based on } 1990 \text { and } 2000 \text { Census } \\
\text { demographics and climate variables) }\end{array}$ \\
\hline
\end{tabular}

\section{DATA}

The data for this study come from five different secondary data sources (see Table 2). These data sources include: CRS participation data as of 2013, Geolytics' Neighborhood Change Database (tract-level Census data, 1970-2010), the Spatial Hazard Events and Loss Database for the United States (SHELDUS) (1960-2013), FEMA's latest Digital Flood Insurance Rate Maps, and flood risk data (1996) from USDOT.

The dependent variables shape the type of method possible as well as the subsample of the overall data set that can be assessed in each case. The first dependent variable, CRS13, is a dummy variable representing whether a community was in CRS in 2013. The second dependent variable, $\triangle C R S$, is a variable representing whether any eligible community (city or county) adopted CRS after the 1998 cohort (and is therefore a dummy variable). We use a linear probability model to estimate both models. The independent variables include demographic variables (e.g. population density, percent college educated, poverty rate, housing values), environmental variables (e.g. humidity, water share, topography), and flood risk variables (e.g. floodplain share, Raster Map-1 km grid cell, flood damage). The demographic controls include initial level measures (circa 2000) as well as percent changes from 2000 to 2010 to capture recent trends. Using flood risk data from the raster maps in the 1990s has the advantage of mitigating potential endogeneity in official flood insurance rate maps, but still requires aggregating up from the $1 \mathrm{~km}$ grid cell to the community level. Thus, we measure community flood risk using the weighted average of tract-level flood risks, with weights defined by tracts' area and population. Trends in flood risk in terms of recent flood event damage and changing population flood risk are also included in the model. 
Table 2. Data sources.

\begin{tabular}{|c|c|c|c|}
\hline Data Source & Unit & Year & Sample Variables \\
\hline CRS Participation from FEMA & $\begin{array}{l}\text { Community } \\
\text { (Place/County) }\end{array}$ & $1993-2013$ & $\begin{array}{l}\text { Name of participating } \\
\text { community, CRS class, } \\
\text { credits earned, etc. }\end{array}$ \\
\hline $\begin{array}{l}\text { US Census: Neighborhood } \\
\text { Change Database (NCDB) from } \\
\text { Geolytics, Inc. }\end{array}$ & $\begin{array}{l}\text { Census Place, } \\
\text { tracts }\end{array}$ & $1970-2010$ & $\begin{array}{l}\text { Mean housing values, } \\
\text { vacant housing, renters, } \\
\text { time in residence, demo- } \\
\text { graphics, etc. }\end{array}$ \\
\hline $\begin{array}{l}\text { The Spatial Hazard Events and } \\
\text { Loss Database for the United } \\
\text { States (SHELDUS) }\end{array}$ & County & $1960-2013$ & $\begin{array}{l}\text { Hazard type, damages, } \\
\text { injuries, fatalities, etc. }\end{array}$ \\
\hline $\begin{array}{l}\text { Flood Insurance Rate Maps } \\
\text { (FIRMs) from FEMA }\end{array}$ & $\begin{array}{l}\text { Local flood } \\
\text { zones }\end{array}$ & Current & $\begin{array}{l}\text { Base flood elevations, } \\
\text { flood zones, floodplain } \\
\text { boundaries, etc. }\end{array}$ \\
\hline $\begin{array}{l}\text { Flood risk data (Raster) from } \\
\text { USDOT }\end{array}$ & $1 \mathrm{~km}$ grid cell & 1996 & $\begin{array}{l}\text { Topography, climate, } \\
\text { water coverage, etc. }\end{array}$ \\
\hline
\end{tabular}

By including measurements from different years, we may introduce some measurement error in the independent variables, assuming that the years being measured are not the 'correct' years, which is not obvious in this case. A resulting attenuation bias allows us to err on the conservative side with our effect estimation, which is preferable to introducing more assumptions or modeling complexity. Also, we estimate the OLS models with robust standard errors, which account for heteroscedasticity that might result from measurement error in variables. Our model in equation (1) allows for substantial flexibility in which time periods are most relevant for measuring community characteristics and flood risks, as lag times for mitigation responses may vary widely in practice and theory offers little guidance to specify exactly which years must be measured. Thus, our estimates of cross-sectional and change models (Table 4) use past measures of flooding and census data (from 1998-2000) as proxies for prior or pre-existing conditions that might influence community mitigation. Identifying more precise lag structures is beyond the scope of this sort of analysis.

\section{RESULTS}

Table 3 shows the summary statistics for all of the variables. According to Table 3, approximately five percent of the communities participated in the CRS in 2013. This is because many of the early adopters in the 1998 cohort remained in the program. About two percent of the eligible communities adopted CRS after 1998, as indicated by the second dependent variable, $\triangle$ CRS.

The results in Table 4 show that a diverse set of control variables are important for both binary indicators of CRS participation (i.e. CRS13 and $\Delta \mathrm{CRS}$ ). Four independent variables are significant across all four models. Specifically, CRS participating communities generally have lower population densities, higher aggregate housing values, higher rentership rates, and flat topography.

Focusing on the results of the two OLS models (Models 1 and 3) in Table 4, we see that there is a consistent positive and significant relationship between CRS participation and the 
Table 3. Summary statistics.

\begin{tabular}{|c|c|c|c|c|}
\hline Variables & Mean & Std. Dev. & Min & Max \\
\hline CRS13 & 0.05 & 0.22 & 0 & 1 \\
\hline$\triangle \mathrm{CRS}$ & 0.02 & 0.13 & 0 & 1 \\
\hline popdens98 & $3.1 \mathrm{E}-04$ & 7.2E-04 & $8.16 \mathrm{E}-08$ & 0.03 \\
\hline srwht00 & 0.87 & 0.17 & 0.002 & 1 \\
\hline adult00 & 0.74 & 0.04 & 0.44 & 1 \\
\hline kids00 & 0.06 & 0.01 & 0 & 0.20 \\
\hline BAshare00 & 0.13 & 0.09 & 0.003 & 0.64 \\
\hline smenty00 & 0.80 & 0.09 & 0.02 & 0.99 \\
\hline unemprt00 & 0.05 & 0.03 & 0 & 0.46 \\
\hline povrat00 & 0.12 & 0.07 & 0 & 0.68 \\
\hline InrmdfamInc00 & 10.98 & 0.32 & 9.63 & 12.44 \\
\hline Inrmdvalhs00 & 11.69 & 0.56 & 2.94 & 14.05 \\
\hline lnraggval00 & 19.21 & 1.48 & 9.63 & 26.87 \\
\hline rentshare 00 & 0.28 & 0.11 & 0.01 & 0.99 \\
\hline popgro 9000 & 1.15 & 0.42 & 0.24 & 32.86 \\
\hline d10BAshare & 1.22 & 0.32 & 0 & 9.92 \\
\hline d10rmdfamInc & 1.01 & 0.13 & 0 & 3.15 \\
\hline d10rmdvalhs & 1.28 & 2.83 & 0 & 337.79 \\
\hline d10raggval & 2.22 & 2.80 & 0 & 185.42 \\
\hline rururb & 3.73 & 2.91 & 0 & 9 \\
\hline JulHumid & 57.57 & 13.22 & 14 & 80 \\
\hline watershare & 7.02 & 14.03 & 0 & 75 \\
\hline flat & 0.51 & 0.50 & 0 & 1 \\
\hline FloodDamMA98 & 129.09 & 1458.15 & 0 & 64975.34 \\
\hline FloodDam98 & 26.47 & 292.17 & 0 & 10193.89 \\
\hline noFIRM & 0.16 & 0.36 & 0 & 1 \\
\hline RiskshareC & 53.63 & 21.48 & 3.38 & 99 \\
\hline RisksharePWC98 & 36.03 & 26.78 & 0.004 & 99 \\
\hline d98FloodDamMA & 5185.57 & 98124.41 & 0 & 2298142 \\
\hline d98RisksharePWC & 1.01 & 0.08 & 0.42 & 7.28 \\
\hline CRS98_W & 0.04 & 0.14 & 0 & 1 \\
\hline CTota198_W & 107.63 & 418.09 & 0 & 11714 \\
\hline FloodDamMA98_W & 489.20 & 3113.87 & 0 & 90465.09 \\
\hline Watershare_W & 28.08 & 51.22 & 0 & 1260.3 \\
\hline $\begin{array}{l}\text { PopGro } \\
\text { (predicted)_W }\end{array}$ & 4.49 & 6.73 & -0.57 & 188.57 \\
\hline
\end{tabular}


Table 4: Cross-sectional (2013) and changes (1998-2013) results.

\begin{tabular}{|c|c|c|c|c|c|c|c|c|}
\hline \multirow[b]{2}{*}{ Variable } & \multicolumn{2}{|c|}{$\begin{array}{c}\text { CRS13 } \\
\text { (OLS Model 1) }\end{array}$} & \multicolumn{2}{|c|}{$\begin{array}{c}\text { CRS13 } \\
\text { (SMM Model 2) }\end{array}$} & \multicolumn{2}{|c|}{$\begin{array}{c}\Delta \text { CRS } \\
\text { (OLS Model 3) }\end{array}$} & \multicolumn{2}{|c|}{$\begin{array}{c}\Delta \text { CRS } \\
\text { (SMM Model 4) }\end{array}$} \\
\hline & Coef. & $\mathbf{p}$ & Coef. & $\mathbf{p}$ & Coef. & $\mathbf{p}$ & Coef. & $\mathbf{p}$ \\
\hline popdens98 & $-18.946^{* * *}$ & 0.000 & $-17.522 * * *$ & 0.000 & $-7.442 * * *$ & 0.000 & $-7.650 * * *$ & 0.000 \\
\hline shrwht00 & $-0.029 * *$ & 0.015 & 0.008 & 0.537 & -0.006 & 0.391 & 0.008 & 0.187 \\
\hline adult00 & 0.026 & 0.699 & 0.115 & 0.106 & $-0.113 * * *$ & 0.009 & -0.067 & 0.108 \\
\hline kids00 & $-0.360 * *$ & 0.039 & -0.114 & 0.582 & $-0.316^{* * *}$ & 0.005 & $-0.231 *$ & 0.057 \\
\hline BAshare00 & $0.229 * * *$ & 0.000 & $0.213 * * *$ & 0.000 & 0.018 & 0.469 & 0.023 & 0.270 \\
\hline smenty00 & $-0.164 * * *$ & 0.000 & $-0.098 * * *$ & 0.000 & $-0.036 * *$ & 0.022 & -0.014 & 0.258 \\
\hline unemprt00 & $-0.114 * *$ & 0.024 & -0.080 & 0.221 & -0.003 & 0.920 & -0.001 & 0.973 \\
\hline povrat00 & -0.024 & 0.563 & 0.004 & 0.922 & -0.003 & 0.893 & -0.003 & 0.902 \\
\hline InrmdfamInc00 & $-0.114 * * *$ & 0.000 & $-0.082 * * *$ & 0.000 & -0.014 & 0.149 & $-0.016^{*}$ & 0.093 \\
\hline lnrmdvalhs00 & $-0.021 * * *$ & 0.001 & $-0.020 * * *$ & 0.002 & -0.005 & 0.242 & 0.001 & 0.845 \\
\hline lnraggval00 & $0.056^{* * *}$ & 0.000 & $0.039 * * *$ & 0.000 & $0.016 * * *$ & 0.000 & $0.006 * * *$ & 0.000 \\
\hline rentshare00 & $0.115 * * *$ & 0.000 & $0.113^{* * *}$ & 0.000 & $0.064 * * *$ & 0.000 & $0.060 * * *$ & 0.000 \\
\hline popgro9000 & $-0.007 * *$ & 0.018 & $-0.010^{*}$ & 0.077 & 0.004 & 0.303 & 0.004 & 0.173 \\
\hline d10BAshare & $0.014 * * *$ & 0.000 & $0.013^{* *}$ & 0.013 & $0.006 * *$ & 0.012 & 0.005 & 0.115 \\
\hline d10rmdfamInc & -0.004 & 0.749 & -0.007 & 0.551 & -0.004 & 0.497 & -0.004 & 0.563 \\
\hline d10rmdvalhs & 0.0003 & 0.124 & -0.0003 & 0.813 & $3.1 \mathrm{E}-05$ & 0.910 & 4.2E-05 & 0.954 \\
\hline d10raggval & $0.004 * * *$ & 0.001 & $0.003 * * *$ & 0.000 & $0.001 * *$ & 0.015 & 0.001 & 0.139 \\
\hline rururb & $-0.003 * * *$ & 0.000 & -0.001 & 0.157 & $-0.001 * *$ & 0.015 & $-6.8 \mathrm{E}-05$ & 0.868 \\
\hline JulHumid & -0.0001 & 0.347 & -0.0001 & 0.292 & $1.2 \mathrm{E}-04$ & 0.217 & $1.1 \mathrm{E}-04 *$ & 0.084 \\
\hline watershare & $0.001 * * *$ & 0.000 & $0.001 * * *$ & 0.000 & $6.8 \mathrm{E}-05$ & 0.453 & 7.3E-06 & 0.899 \\
\hline flat & $0.014 * * *$ & 0.000 & $0.015^{* * *}$ & 0.000 & $0.005^{* *}$ & 0.026 & $0.005 * * *$ & 0.004 \\
\hline FloodDamMA98 & $1.5 \mathrm{E}-06$ & 0.274 & $1.2 \mathrm{E}-06$ & 0.256 & $-1.6 \mathrm{E}-07$ & 0.480 & $-1.6 \mathrm{E}-07$ & 0.794 \\
\hline FloodDam98 & $-4.9 \mathrm{E}-06^{*}$ & 0.072 & $-3.7 \mathrm{E}-06$ & 0.476 & $1.1 \mathrm{E}-06$ & 0.575 & $9.2 \mathrm{E}-07$ & 0.742 \\
\hline noFIRM & -0.002 & 0.692 & 0.0003 & 0.941 & -0.002 & 0.541 & 0.0004 & 0.856 \\
\hline RiskshareC & $-4.2 \mathrm{E}-04 * * *$ & 0.005 & $-1.8 \mathrm{E}-04$ & 0.100 & $2.0 \mathrm{E}-05$ & 0.841 & $1.3 \mathrm{E}-04 * *$ & 0.028 \\
\hline RisksharePWC98 & $6.7 \mathrm{E}-04 * * *$ & 0.000 & $4.1 \mathrm{E}-04 * * *$ & 0.000 & $3.4 \mathrm{E}-05$ & 0.705 & $-1.0 \mathrm{E}-04$ & 0.140 \\
\hline d98FloodDamMA & $2.9 \mathrm{E}-08$ & 0.100 & $1.8 \mathrm{E}-08$ & 0.248 & $-9.6 \mathrm{E}-09 * * *$ & 0.002 & $-3.9 \mathrm{E}-09$ & 0.626 \\
\hline d98RisksharePWC & $0.124 * * *$ & 0.000 & $0.121 * * *$ & 0.000 & 0.050 & 0.163 & $0.052 * * *$ & 0.000 \\
\hline \multicolumn{9}{|l|}{$\begin{array}{l}\text { Neighborhood } \\
\text { Attributes }\end{array}$} \\
\hline CRS98_W & & & & & -0.006 & 0.443 & & \\
\hline CTota198_W & & & & & $9.3 \mathrm{E}-06$ & 0.267 & & \\
\hline FloodDamMA98_W & & & & & $-1.4 \mathrm{E}-07$ & 0.523 & & \\
\hline Watershare_W & & & & & $-1.9 \mathrm{E}-05$ & 0.569 & & \\
\hline $\begin{array}{l}\text { PopGro } \\
\text { (predicted)_W }\end{array}$ & & & & & $6.1 \mathrm{E}-05$ & 0.823 & & \\
\hline constant & $0.457 * *$ & 0.018 & 0.228 & 0.244 & -0.019 & 0.877 & 0.035 & 0.757 \\
\hline Spatial lag: $\lambda$ & & & $0.049 * * *$ & 0.000 & & & $0.074 * * *$ & 0.000 \\
\hline
\end{tabular}




\begin{tabular}{lllll}
\hline Spatial error: $\rho$ & & $-0.006^{*}$ & 0.060 & $-0.075^{* * *} 0.000$ \\
$\mathrm{~N}$ & 18165 & 18095 & 18095 & 18095 \\
$\mathrm{~F}$ & 30.64 & & 8.76 & \\
Prob $>\mathrm{F}$ & 0 & & 0 & \\
R-squared & 0.112 & & 0.032 & \\
Root MSE & 0.205 & 0.133 & \\
\hline
\end{tabular}

Note: $* \mathrm{p}<.1, * * \mathrm{p}<.05, * * * \mathrm{p}<.01$

percentage of individuals with at least a college degree, aggregate housing value, rentership rate, change in housing value, and flat topography. In addition, there is a negative and significant relationship between CRS participation and population density, the percentage of children under the age of five, the percentage of people living in same county 5 years prior, and ruralness. In Model 3, we add in some more 'spatial lags of neighbor attribute' measures to test whether neighboring flood experience and water coverage (both measures of potential spillover or adjacent flood risk) and neighboring population growth rates also predict more post-1998 participation.None of these additional neighborhood variables, based on the results of Model 3, suggest a significant effect.

The results of the two SMM models (Models 2 and 4) in Table 4 show a consistent positive and significant relationship between CRS participation and aggregate housing value, rentership rate, flat topography, and population-weighted flood risk change from 1990-1998. Conversely, CRS participation is significant and negatively associated with population density and median family income.

Some environmental factors and flood-risk variables influence participation in the CRS, although not consistently throughout the four models. Regarding environmental factors, water share is a positive and significant predictor of CRS participation in two models. The following flood-risk variables are also significant predictors of CRS participation in at least two of the four models: area-weighted average flood risk, population-weighted average flood risk, and population-weighted flood risk change from 1990-1998.

\section{CONCLUSION}

Floods are considered the most destructive natural hazard in terms of lives lost, injuries, and economic losses. For example, the 30-year average for flood-related deaths and damages in the United States between 1982 and 2011 are 95 fatalities and $\$ 8.20$ billion, respectively. Floods are likely to continue to wreak havoc on communities given existing and predicted climate change impacts such as increases in frequency and intensity of heavy precipitation events and the melting of glacier ice. The United States government created the CRS program to provide additional incentives to communities who are interested in voluntarily engaging in flood mitigation initiatives to stem the destruction engendered by floods. Although previous studies have examined the drivers of CRS adoption, no study has investigated whether CRS participation is a function of policy diffusion or an act of free-riding. Policy diffusion would suggest that, all else being equal, once a community has joined the CRS, neighboring communities will be more likely to follow their lead and participate in the CRS. Free-riding would imply that neighboring communities might choose not to participate in the CRS because they perceive that their community benefits from surrounding communities participating in the CRS.

This study finds that CRS participation in 1998 by neighbors, points earned in 1998 by neighbors, neighboring flood experience, water coverage of neighbors, and neighboring 
population growth rates have no influence on CRS participation. This finding is important because it indicates that a community's decision to participate in the CRS is not influenced by the characteristics of or the behavior their neighbors. In short, there is no evidence to support the hypothesis that neighboring communities of CRS participating communities are free-riders (benefit from the CRS program via their CRS participant neighbors).

However, the results of this study do show that population density, aggregate housing values, rentership rate, and flat topography are significant predictors of CRS participation both cross-sectionally (CRS13) and as a change $(\triangle C R S)$. CRS participating communities generally have lower population densities, higher aggregate housing values, higher rentership rates and their topographies are usually flat. Higher renter-occupancy rates and housing values among CRS participating communities perhaps suggest more local advocacy efforts by renters and homeowners to push politicians to participate in CRS with the potential benefit of having a larger property tax base to fund mitigation activities or the need to protect their high housing values.

This study also finds that environmental factors and flood-risk- related variables influence communities' participation in CRS. These results are in line with previous studies which provided evidence that flood risk is an important predictor of community participation in the CRS [3], [8], [9], [18]. In conclusion, CRS participation is driven by demographic characteristics, flood risks, and environmental/geographic factors.

\section{ACKNOWLEDGMENTS}

This material is based upon work supported by the National Science Foundation under Grant No. 1838421. This paper is based on the conference paper: Noonan, D.S., Richardson, L.E. \& Sadiq, A.A., Policy diffusion in community-scale flood risk management. WIT Transactions on Engineering Sciences, Vol 121, WIT Press, 2018, ISSN 1743-3533.

\section{REFERENCES}

[1] Guha-Sapir, D., Hoyois, P. \& Below, R., Annual disaster statistical review 2012: The numbers and trends. Retrieved from http://reliefweb.int/sites/reliefweb.int/files/resources/ADSR_2012.pdf (accessed 18 December 2018).

[2] Weather fatalities 2017; National Weather Service. Retrieved from http://www.nws. noaa.gov/om/hazstats.shtml (accessed on 18 December 2018).

[3] Sadiq, A.A. \& Noonan, D.S., Flood disaster management policy: An analysis of the United States community ratings system. Journal of Natural Resources Policy Research, 7(1), pp. 5-22, 2015. https://doi.org/10.1080/19390459.2014.963373

[4] Sadiq, A.A. \& Noonan, D.S., Local capacity and resilience to flooding: Community responsiveness to the community ratings system program incentives. Natural Hazards, 78(2), pp. 1413-1428, 2015. https://doi.org/10.1007/s11069-015-1776-9

[5] Dixon, L., Clancy, N., Seabury, S.A. \& Overton, A., The national flood insurance program's market penetration rate, estimates and policy implications. Retrieved from http://www.rand.org/content/dam/rand/pubs/technical_reports/2006/RAND_TR300. pdf (accessed 18 December 2018).

[6] National Flood Insurance Community Rating Systems Coordinator's Manual; Federal Emergency Management Agency, FIA-15/2017, OMB No. 1660-0022, Online. Retrieved from www.fema.gov/media-library/assets/documents/8768 (accessed 18 December 2018).

[7] Burby, R.J., Flood insurance and floodplain management: The US experience. Global Environmental Change Part B: Environmental Hazards, 3(3-4), pp. 111-122, 2001. https://doi.org/10.1016/s1464-2867(02)00003-7 
[8] Landry, C.E. \& Li, J., Participation in the community rating system of NFIP: Empirical analysis of North Carolina counties. Natural Hazards Review, 13(3), 205-220, 2012. https://doi.org/10.1061/(asce)nh.1527-6996.0000073

[9] Posey, J., The determinants of vulnerability and adaptive capacity at the municipal level: Evidence from floodplain management programs in the United States. Global Environmental Change, 19(4), pp. 482-493, 2009. https://doi.org/10.1016/j.gloenvcha.2009.06.003

[10] Brody, S.D., Zahran, S., Highfield, W.E., Bernhardt, S.P. \& Vedlitz, A., Policy learning for flood mitigation: A longitudinal assessment of the Community Rating System in Florida. Risk Analysis, 29(6), pp. 912-929, 2009. https://doi.org/10.1111/j.15396924.2009.01210.x

[11] Zahran, S., Weiler, S., Brody, S.D., Lindell, M.K. \& Highfield, W.E., Modeling national flood insurance policy holding at the county scale in Florida, 1999-2005. Ecological Economics, 68(10), pp. 2627-2636, 2009. https://doi.org/10.1016/j.ecolecon.2009.04.021

[12] Noonan, D.S. \& Sadiq, A.A., Community-scale flood risk management: Effects of a voluntary national program on migration and development. Ecological Economics, 157, pp. 92-99, 2019. https://doi.org/10.1016/j.ecolecon.2018.11.005

[13] Noonan, D.S. \& Sadiq, A.A., Flood risk management: Exploring the impacts of the community rating system program on poverty and income inequality. Risk Analysis, 38(3), pp. 489-503, 2018. https://doi.org/10.1111/risa.12853

[14] Asche, E.A., The Effect of Flood Risk on Housing Choices and Community Hazard Mitigation, PhD Thesis, University of California at Santa Barbara, 2013.

[15] Fan, Q. \& Davlasheridze, M., Flood risk, flood mitigation, and location choice: evaluating the national flood insurance program's community rating system. Risk Analysis, 36(6), pp. 1125-1147, 2016. https://doi.org/10.1111/risa.12505

[16] Li, J. \& Landry, C.E., Flood Risk, local hazard mitigation, and the community rating system of the national flood insurance program. Land Economics, 94(2), pp. 175-198, 2018. https://doi.org/10.3368/le.94.2.175

[17] Kahn, M.E., The death toll from natural disasters: The role of income, geography, and institutions. Review of Economics and Statistics, 87(2), pp. 271-284, 2005. https://doi. org/10.1162/0034653053970339

[18] Zahran, S., Brody, S.D., Highfield, W.E. \& Vedlitz, A., Non-linear incentives, plan design, and flood mitigation: The case of the federal emergency management agency's community rating system. Journal of Environmental Planning and Management, 53(2), pp. 219-239, 2010. https://doi.org/10.1080/09640560903529410 